\title{
ADENTRARSE EN EL MUNDO DEL SÍMBOLO. LA FORMACIÓN ESTÉTICA EN CONTEXTOS EDUCATIVOS
}

María del Carmen Bernal González

VIVIR EN EL MUNDo de LA EDUCACIÓn PUEDE SER UNA DE LAS AVENTURAS más emocionantes de la vida. Para los que nos dedicamos a tan noble labor, supone una capacidad de asombro, apertura y magnanimidad constantes para viajar por espacios poco visitados, que permitan tener un conocimiento más amplio y completo del sustento de nuestro estudio: la persona humana, así como desarrollar los medios adecuados para ayudarla a aspirar - como lo diría Goethe -, con un esfuerzo ininterrumpido, a la forma más alta de existencia. ${ }^{1}$

El espacio al que nos acercaremos en este artículo es el Mundo del Símbolo, conformado por un conjunto de signos que expresan realidades específicas y que son percibidas por una subjetividad concreta. El símbolo que es una realidad transfísica que busca ser reconocida, y posibilita el aprendizaje, mediante la relación estrecha entre percibir y simbolizar. Acogida y reconocimiento son pues, sus aspectos esenciales. ${ }^{2}$

La capacidad de percibir los símbolos es llevada a cabo por una persona que imprime una parte considerable de su subjetividad tratando de entender el mensaje que expresan, "es el núcleo activo de conformación de la totalidad de lo percibido, de lo que puede ser reconocido y acogido. La simbolización se realiza desde un sujeto, y esto conlleva que dicha subjetividad es el núcleo originario de donación de sentido a lo simbolizado. Las cosas reales mantienen un sentido propio en el conocimiento; pero en cuanto que re-conocidas, adquieren un nuevo sentido - un sentido simbólico - que es otorgado por la subje- 
tividad." ${ }^{3}$ Son la imaginación y la memoria los sentidos internos que intervienen directamente en la construcción de los símbolos, favoreciendo el conocimiento y diálogo con la realidad. Ya lo decía Cassirer "el hombre no puede enfrentarse ya con la realidad de modo inmediato; no puede verla, como si dijéramos cara a cara. La realidad física parece retroceder en la misma proporción que avanza su capacidad simbólica. En lugar de tratar con las cosas mismas, en cierto sentido conversa constantemente consigo mismo. Se ha envuelto en formas lingüísticas, en imágenes artísticas, en símbolos míticos o en ritos religiosos, en tal forma que no puede ver o conocer nada sino a través de la interposición de este medio artificial". ${ }^{4}$ Se ha de admitir que este proceso no se da de manera radical y exclusiva, dado que el ser humano se conoce a sí mismo y a su entorno mediante la reflexión del mundo por medio de estas representaciones, por ello resulta importante tomarlas en cuenta en el quehacer educativo. ${ }^{5}$ Una de estas realidades simbólicas es el arte, lenguaje de expresión humana por excelencia, que ha acompañado y enriquecido al hombre desde sus orígenes. A través del arte el ser humano ha puesto el signo de lo bello en las obras que hace, expresando sus ideas, sentimientos, el mundo en el que vive y el juego entre su interioridad y exterioridad con una envoltura apetecible. El contacto con el arte verdadero, enriquece, eleva el espíritu y mejora la calidad de vida, de ahí que sirva como experiencia y encuentro de que merece la pena abrir la sensibilidad al entorno e incorporar la belleza al vivir cotidiano. Las obras de arte permiten descubrir la interrelación de las cosas, dirigen nuestra atención a las relaciones que tienen los elementos dentro de una totalidad, desarrollan la capacidad de atender no a lo monumental sino a las cosas pequeñas y a los aspectos internos de la experiencia; forman la percepción y favorecen la apreciación de lo que previamente parecía insignificante. ${ }^{6}$ Es por ello que el arte es considerado como un lenguaje simbólico por excelencia, ya lo decía Dewey: “El arte 
es la prueba vivida y concreta de que el hombre es capaz de restaurar conscientemente, y esto en el plano del significado, de la unidad de sentido, de la necesidad y del impulso y acción característicos de la criatura viva. La intervención de la conciencia añade regulación, capacidad de selección y redisposición. De esta forma, hace que las artes varíen infinitamente. Pero, con el tiempo, la intervención de la conciencia conduce también a la idea de que el arte en tanto que idea consciente es el mayor logro intelectual en la historia de la humanidad". ${ }^{7}$

El arte, por ser un símbolo constructo, presenta a la percepción el conocimiento de formas de sentimiento de un ser humano. Así lo expresa Langer : " una obra de arte expresa el sentimiento (en el sentido amplio que he mencionado antes, como todo aquello que se puede sentir) para que lo contemplemos, haciéndolo visible, audible o de alguna manera perceptible a través de un símbolo, no deducible de un indicio. La forma artística es congruente con las formas dinámicas de nuestra inmediata vida sensible, mental y emocional; las obras de arte son proyecciones de vida sensible, como las llamó Henry James, en estructuras espaciales, temporales y poéticas. Son imágenes del sentimiento, imágenes que formulan el sentimiento para nuestra cognición. Todo aquello que articula el sentimien to y lo presen ta a nuestro conocimien to es artísticamente bueno."8 Es evidente por tanto, que la elaboración humana que llamamos estética, ofrece una gama inigualable de posibilidades en el proceso educativo, proporcionando un conocimiento más vivo del mundo y haciendo una aportación única a la experiencia individual: por ejemplo, a lo largo de las distintas épocas, el arte ha servido para que lo espiritual, se hiciese visible a través de la imagen. Ya lo decía Kandinsky: "el arte es el lenguaje que habla al alma de cosas que son para ella el pan cotidiano, que sólo puede recibir en esta forma" ${ }^{\prime}$. Cuando el arte desempeña esta función, da a lo personal e inefable una forma pública en la 
cual pueden participar otros, y de esta forma, las ideas de una cultura pueden asumir una significación colectiva que no tendrían de ningún otro modo. ${ }^{10}$ Estas son algunas de las funciones que el arte aporta a la educación, de ahí que sea necesario darle un lugar dentro de los contextos educativos. Es a través de la formación estética como se llevará a cabo esta tarea; siendo un ámbito profesional en el cual el educador debe incursionar, dado que permite una aproximación con las obras de arte que encierran una dimensión nueva y un canal extraordinario de expresión para el crecimiento espiritual, ya que por medio de ellas, el artista habla y se comunica con los otros introduciendo en el conocimiento de su intimidad y revelando la original contribución que ofrecen a la historia de la cultura. ${ }^{11}$ Esto conduce a la posibilidad de tomar el agrado como signo de la presencia de un valor misterioso -el arte- que nos abre a la riqueza de las imágenes, más allá de las simples figuras, y que nos enseña a ver con mayor profundidad y relieve más nítido la vida. El educador con mayores recursos podrá acercarse al mundo del símbolo para alcanzar una educación integral, armónica y relevante.

\section{PRINCIPIOS BÁSICOS DE LA FORMACIÓN ESTÉTICA}

En primer lugar conviene precisar que la intervención educativa en función del arte y la belleza resulta en algunas ocasiones difícil, por tratarse de temas polémicos. No obstante, los educadores que participamos en este ambicioso proyecto estamos convencidos de que es un campo fértil que ofrece posibilidades en muchos sentidos, basta mencionar como un ejemplo, la educación de la urbanidad y la cortesía, virtudes sociales que en la actualidad se han olvidado por el deterioro espiritual y humano que ha sufrido la persona al carecer de educación estética; quien sabe apreciar lo bello (natural o artístico) desarrolla una sensibilidad fina( buen gusto) que le permitirá elegir las maneras o 
modales acordes a su dignidad y verá en los otros un reflejo de su propia identidad.

La formación estética ${ }^{12}$ consiste en la promoción y desarrollo de la capacidad para descubrir, apreciar, simbolizar y recrear la belleza donde se encuentre. En este sentido abarca no solamente la belleza expresada en las producciones artísticas sino también esa belleza que emana de la naturaleza; ambas como ya se ha mencionado influyen en todos los aspectos de la vida humana.

La educación estética pretende: orientar la sensibilidad del ser humano por medio del encuentro con la belleza y el arte, haciéndolo consciente de sus emociones. Busca en definitiva la armonía y reconciliación entre la esfera de la racionalidad y la esfera de la sensibilidad. Se potencia la capacidad de desarrollar posibilidades para crear un ambiente agradable, para adornar con medida las acciones, producciones y pertenencias humanas con un aspecto más atractivo y agradable que guste a sí mismo y a los demás. ${ }^{13}$ Esta formación se caracteriza por el aprecio de lo elegante y distinguido en todas las manifestaciones de la vida, superando lo vulgar, lo feo, lo imperfecto , y enriqueciendo el espíritu. Se expresa en todo: en el modo de hablar, de vestir, de trabajar, en las relaciones humanas, en lo que se compra y en lo que se usa, en lo que se estima y rechaza. Todo ello denota buen gusto y un cierto talento que proporciona la afinidad con los valores, gracias a que se ha atendido la educación del sentido estético que como decía Ingres: "un gusto fino y delicado es fruto de la educación y de la experiencia". ${ }^{14}$ La educación estética por tanto modela la capacidad perceptiva, influye en la imaginación, en la memoria y trasciende la sensibilidad mediante la identificación de los elementos y las relaciones artísticas, las clases de significación de los diferentes lenguajes propios de cada arte, influyendo directamente en la capacidad intuitiva para ver directamente la perfección e imperfección de una realidad o de un acto humano, y desarrollando la capacidad de contemplación. ${ }^{15}$ 
La dificultad de la educación estética radica en que los educadores deben mostrar el objeto estético como algo cercano, a pesar de que sea algo distinto, deben enseñar el significado de las imágenes, de los movimientos, de los ritmos, de la belleza de muchas conductas de personajes grandes o pequeños, en fin, deben propiciar el encuentro con un sinnúmero de lenguajes artísticos que encierran un mundo misterioso por descubrir y apreciar; sin embargo, desafortunadamente no todos cuentan con una formación estética de base que les permita desarrollar esta tarea. Por ello, es necesario que los profesionales de la educación cuenten entre sus competencias con una sólida formación estética, que les permita orientar la sensibilidad de sus educandos - tan necesario en la actualidad- mediante el contacto con la belleza y su incorporación a la vida cotidiana.

A manera de conclusión conviene resaltar que el arte es una gran ayuda para el educador, porque pone en sus manos la experiencia de otros seres humanos para que sea compartida y revivida. Condensa en sus imágenes los grandes temas de la existencia humana y muestra al hombre en sus múltiples dimensiones, en sus acciones, con sus pasiones, con sus motivaciones y valores vitales, ${ }^{16}$ siendo en sí mismo un gran tesoro que la educación debe aprovechar. Lo vemos por ejemplo en los libros, que " nos conceden el privilegio mágico de seguir escuchando voces que hace mucho tiempo se apagaron, de visitar lugares a los que no iremos nunca y de hablar íntimamente con hombres y mujeres cuyos rostros y vida desconocemos." ${ }^{17}$ Todo este mundo es posible gracias a la capacidad simbólica y poder formativo del arte que permite educar a personas para que sean capaces de intuir lo que no desaparecerá con el tiempo, tengan claridad de expresión, amplitud en el campo del conocimiento y equilibrio al tratar de desentrañar la realidad sin obnubilarse por ningún factor o dimensión, pasando incluso por encima de las modas. ${ }^{18}$

La formación estética es la peor enemiga de la mediocridad 
y de lo mundano, el contacto con las obras de arte ayudará a redescubrir el sentido del mundo, desarrollará un importante papel en el desarrollo de la sensibilidad y funcionará como imagen de lo que podría ser la vida. ${ }^{19}$

\section{REFERENCIAS BIBLIOGRÁFICAS}

${ }^{1}$ IBAÑEZ- MARIN, J.A., Hacia una formación Humanística. Objetivos de la educación en la sociedad científico - técnica, Herder, Barcelona, 1989, 13.

${ }^{2}$ Cf. ALTAREJOS, F., Dimensión ética de la educación, EUNSA, Navarra, 1999,46. ${ }^{3} \mathrm{Ib} .47-48$.

${ }^{4}$ CASSIRER, E., Antropología Filosófica, F.C.E. México, 1974, 47.

${ }^{5}$ Cf. ALTAREJOS, F., o.c, 57.

${ }^{6}$ Cf. EISNER, E., Educar la visión artística, Paidós, Barcelona, 1975, 256-257.

7 DEWEY, J., Art as experience, Minton Balch \& Company, New York, 1934, 30. ${ }^{8}$ LANGER, K.S., Expressiveness problems of art, Scribner's Sons, New York, 1957, 13-26. Elliot Eisner estudioso de la educación estética reconoce en su o.c. la competencia de la autora en la estética.

${ }^{9}$ KANDINSKY, V., De lo espiritual en el arte, Paidós, Barcelona, 1997, 102.

10 Cf. EISNER, E., o.c, 10.

${ }^{11}$ JUAN PABLO II., Carta del Santo Padre Juan Pablo II a los artistas, Ciudad del Vaticano, 1999, 3.

${ }^{12}$ A lo largo de este artículo se entiende por lo mismo educación y formación estética. No en cambio por educación artística, caracterizada por la promoción y refuerzo de la capacidad para realizar obras de arte, es decir, obras bellas producidas por la actividad humana. Para ello, se requiere un cierto talento o genio artístico que no todas las personas poseen. Cf. GARCIA, HOZ, V., et.al., Enseñanzas artísticas y técnicas, RIALP, Madrid, 1996, 75.

${ }^{13}$ Cf. QUINTANA CABANAS, J., Pedagogía Estética, Dykinson, Madrid, 1993, 11.

${ }^{14} \mathrm{Ib}$. 365, el autor cita estas palabras del pintor Ingres que confirman que la facultad del gusto es susceptible de educarse.

${ }^{15}$ Cf. Ib., 81.

${ }^{16}$ Cf. AMIGO, FERNÁNDEZ DE A, M.L, "El arte en el ámbito del ocio: su aportación a la educación del receptor," en Revista de Ciencias de la Educación, no. 165, enero - marzo 1996, 67.

${ }_{17}$ MUÑOZ, MOLINA, A., ¿Porqué no es útil la literatura?, Hiperión, Madrid, 1993, 65-66. 
${ }^{18}$ Cf. IBAÑEZ - MARIN, J.A., o.c, 66.

${ }^{19}$ Cf. EISNER, E., o.C, 11.

\section{BIBLIOGRAFIA}

ALTAREJOS, F., Dimensión ética de la educación, EUNSA, Navarra, 1999.

AMIGO , FERNANDEZ DE A. M.L, "El arte en el ámbito del ocio: su aportación a la educación del receptor," en Revista de Ciencias de la educación, no. 165, enero - marzo 1996.

CASSIRER, E., Antropología Filosófica, Fondo de Cultura Económica, México, 1974.

DEWEY, J., Art as experience, Balch \& Company, New York , 1934.

EISNER, E., Educar la visión artística, Paidós, Barcelona, 1975.

IBAÑEZ - MARIN, J.A., Hacia una formación humanística. Objetivos de la educación en una sociedad científico - técnica. Herder, Barcelona, 1989.

JUAN PABLO II, Carta del Santo Padre Juan Pablo II a los artistas, Ciudad del Vaticano, 1999.

KANDINSKY, V., De lo espiritual en el arte, Paidos, Barcelona, 1997.

LANGER, K.S., Expressiveness, problems of art, Scribner's Sons, New York, 1957. MUÑOZ, MOLINA, A., ¿Porqué no esútil la literatura?, Hiperión, Madrid, 1993. QUINTANA, CABANAS, J.M., Pedagogía Estética, Dykinson, Madrid, 1993. 